\title{
The Implementation of Good Governance Practices in Service Provisions to the Citizens in Addis Ababa City Administration: The Case of Yeka Sub-City ${ }^{1}$
}

\section{DABA MOTI ${ }^{2}-$ CHUOL KOMPUOK $^{3}$}

Addis Ababa city administration is known for its poor implementation of good governance to the public. The main objective of the study is to assess the implementation of good governance while rendering services to the ordinary citizens. The research methodology employs both quantitative and qualitative approaches using data collection instruments with the IBM SPSS statistical packagxe vs. 21. The findings indicate favourable results in meeting the needs of citizens. To that effect, a number of issues are discussed: good governance that is effective and efficient, transparent and open, accountable; participation, leadership direction and strategic vision; fairness and equity; governance that is consensus oriented, responsive in service provision; and governance that follows the rule of law. Although the implementation process has brought tangible results, it is not free from some challenges. In conclusion, both achievements and failures were observed. Thus, understanding customers' expectations in service provisions, systematising customers' feedback, and continuously raising the staff's awareness are the recommendations identified for future development.

Keywords: governance, elements of good governance, service provisions, citizens, Addis Ababa, Yeka Sub-City

1 First and foremost, we are profoundly indebted to our university, the Ethiopian Civil Service University (ECSU), which sponsored the whole cost of covering all the expenses that helped us accomplish the study. The authors are also grateful to all the service users of the institutions in giving their own responses in accordance with the data collection instruments.

2 Daba Moti Duguma, Director of Consultancy, Coordination Directorate, Ethiopian Civil Service University

3 Chuol R. Kompuok, PhD, African Institute of Governance and Development, Ethiopian Civil Service University, e-mail: ckompuok2014@gmail.com 


\section{Introduction - Background of the study}

The good governance concept is incorporated in the Millennium Development Goals (MDGs) as the main component of the battle against poverty and for economic development. Good governance refers to the prevalence of government accountability, transparency in decision making, implementing the rule of law and regulations, early responsiveness to the demand of citizens, equity and inclusiveness among interest groups, effectiveness, and efficiency in resource utilisation in service delivery approach. ${ }^{4}$ Governance is also a complex management practice through which citizens and interest groups of the country articulate their expressions and exercise their rights in the decision-making process. Good governance strategy is representative of a successful public sector institutions reform program, its implementation process is complex. ${ }^{5}$ The concept of public or civil service sector reform and good governance has evolved from isolated occurrences and is now seen largely as a global issue. The practice of governance associated with public sector reform programs has led to the formalisation of good governance. ${ }^{6}$ The Mo Ibrahim Foundation defines good governance as the service provider in relation to political, social, and economic public goods and services. Each of these contains sub-categories under which various indicators have been organised that provide quantifiable measures of the overarching dimensions of governance. ${ }^{7}$

The Ethiopian federal system of government that was adopted resulted in open, transparent, and democratic governance that respects the right of all citizens; the introduction of the decentralisation process gave power to regional governments to implement development policies and strategies and provided the opportunity for residents to participate in development programs. ${ }^{8}$ The Ethiopian government has begun implementing reform in good governance due to service delivery dissatisfaction of citizens of the country and growing consensus that it is the root cause of all-round crises in the public sector. ${ }^{9}$ The civil service reforms taking place in Ethiopia are meant for building the capacity for the implementation of good governance in the

4 S Dibaba, 'Opportunities and Challenges for Good Governance in Ethiopia', The Ethiopian Herald, October 8, 2015. Available: https://allafrica.com/stories/201510091427.html (20. 03. 2020)

5 M Worku, Assessment of the Prevalence of Good Governance in the Public Sector: the Case of Selected Public Institutions in the Addis Ababa City of Ethiopia, MA Thesis, Addis Ababa, Ethiopia, 2013.

6 'Good Governance', Wikipedia. Available: https://en.wikipedia.org/wiki/Good_governance (05. 03. 2020.)

7 Z Umar, 'Constructing the 2017 Ibrahihm Index of African Governance', Index Report, Mo Ibrahim Foundation, October 11, 2017. Available: https://mo.ibrahim.foundation/news/2017/constructing2017-ibrahim-index-african-governance (12. 07. 2020.)

8 K Yirga, Assessment of the Prevalence of Good Governance in the Public Sector: The Case of Public Institutions in Debre Birhan Town, MA Thesis: Mekelle University, Ethiopia, 2010.

9 MC Amedie, The Significance and Practice of Good Governance in Addis Ababa, Ethiopia. The Case of Bole Sub-city, MA Thesis, Addis Ababa: Indira Gandhi National Open University, 2014. 
country. ${ }^{10}$ Yeka Sub-City, one of the Addis Ababa City Administrations spearheads the provision of services to its citizens. Ostensibly, Yeka administration and government appeared to have committed its resources to achieve political and socio-economic development through positive implementation of good governance.

\section{Problem statement}

Ethiopia has been faced with challenges in implementing good governance in the country. To address the challenges in building good governance, the government developed a multi-sectorial national capacity building strategy. ${ }^{11}$ Despite the fact that Ethiopia is endowed with resources that can help bring about economic miracles for the country, poor governance has contributed to the country's lowest economic and social indicators..$^{12}$ According to Alemu and Lemma, the inefficiencies and ineffective processes of organisational structure, management practices, outdated work processes and procedures affected the governance system of the public sectors in Ethiopia. ${ }^{13}$ Addis Ababa City Administration doubled as the city is the seat of the Africa Union (AU) with various international organisations, and the capital city of Ethiopia, that is providing services to its citizens. Addis Ababa city organised its Administration institutions' levels in ten sub-cities, with Yeka Sub-City included. Although achievements of the good governance implementation process in the city administration have been observed, the institutions are not free from the challenges of bad governance.

According to Amedie, the performance of Addis Ababa City Administration indicated that there is poor accountability, lack of transparency, poor customer satisfaction, and ill commitment of leaders at all levels of the administration. ${ }^{14}$ The poor capacity and absence of skilled staff resulted in poor service delivery processes. The magnitude of the challenges is more reflected at the district administration office level where services to citizens within the city are required. Because of these research facts, it requires more efforts to practice good governance in the government institutions to respond to the needs of the citizens. Therefore, this study attempts to identify the gaps of the prior research by examining the performance of the implementation of good governance and the root causes of these problems. The study will also make an important attempt in identifying the current trend and factors hindering the implementation of good governance in public service institutions of Addis Ababa City Administration. The variables that would be treated in the study

10 ECSU, Institute of Leadership and Good Governance. Engendering Economic Governance. Addis Ababa: Addis Ababa University, 2017.

11 A Bekele, The Challenges and Prospects of Good Governance in Africa: The Case of Kenya, MA Thesis, Addis Ababa: Addis Ababa University, 2013.

12 Dibaba, 'Opportunities and Challenges'.

13 T Alemu and M Lemma, 'The Contribution of Service Delivery Reform to Promote Good Governance: A Case of Addis Ababa', Ethiopian Journal of Public Management and Development 2, no 1 (2011).

14. Amedie, The Significance and Practice. 
include effectiveness and efficiency, transparency, accountability, participation, leadership direction, fairness and equity, responsiveness, and rule of law. Based on this background information, the study used the following basic research questions.

a) What are the practices of good governance in the studied area?

b) What are the implementation performances of the elements of good governance?

c) What challenges the institutions face in implementing the elements of good governance?

The main objective of the study is to assess the implementation of good governance practices while rendering services to the citizens. Public institutions of Addis Ababa city administration have been providing services at each bureau, sub-city and district administration office levels. Since it is difficult to investigate all the levels of the city administration, the study focused only on Yeka sub-city. From this sub-city, three district administration offices were selected for the study. Due to the unknown real number of customers / service users of the administration offices, the number of respondents was restricted to be selected randomly using the probability approach. The findings of the study will help decision-makers and members of the administration in improving good governance which can lead them to efficiency and effectiveness.

\section{Conceptual frameworks of good governance}

Good governance is defined in various international studies. It stresses the importance of participation of several actors in government affairs so that everyone be entitled to an international order in which the rights and freedoms can be fully realised. ${ }^{15} \mathrm{Good}$ governance refers to the prevalence of government accountability, transparency in decision making, implementing the rule of law and regulations, early responsiveness to the demand of citizens, equity and inclusiveness among interest groups, effectiveness, and efficiency in resource utilisation in service delivery approach. ${ }^{16}$ Good governance has to address the interest of stakeholders in policy initiatives. ${ }^{17}$ Good governance is the mechanism through which citizens articulate their legal rights, responsibilities and meet their obligations. The voices of the poorest, disadvantaged class and the most vulnerable communities are heard in decision-making process over the allocation of resources and decisions passed. Good governance depends on the interaction among stakeholders and leaders and requires the exercise of legal frameworks that

15 A Legas, Parliamentary Oversight and Its Role in Ensuring Accountability. The Case of Caffee Oromia, MA Thesis, Addis Ababa: Addis Ababa University, 2015.

16 Dibaba, 'Opportunities and Challenges'.

17 R Dayanandan, 'Good Governance Practice for Better Performance of Community Organizations - Myths and Realities!!' Journal of Power, Politics E Governance 1, no 1 (2013), $10-26$. 
are enforced impartially to ensure equity among citizens. In this regard, rules and regulations that are implied should be clear and friendly enough to the public. ${ }^{18}$

The implementation of good governance has eight major elements. ${ }^{19}$ These are accountability, transparency and openness, early responsive manner, equity and inclusiveness of the interest groups, effectiveness and efficient utilisation of resources, applying the rule of law, following participatory approach in the decisionmaking process, and being consensus-oriented among interest groups. On the other hand, according to Khanna, the good governance framework consists of seven basic principles as shown in Figure 1 below. ${ }^{20}$ Even though different kinds of literature describe a different number of elements of good governance, almost all of them have similar concepts. Thus, according to the ESCAP ${ }^{21}$ and Khanna, ${ }^{22}$ the following seven elements or principles and practices would become common tools for improving the service delivery and management strategy for achieving good governance as well as filling gaps that may exist between the current and desired state of governance affairs.

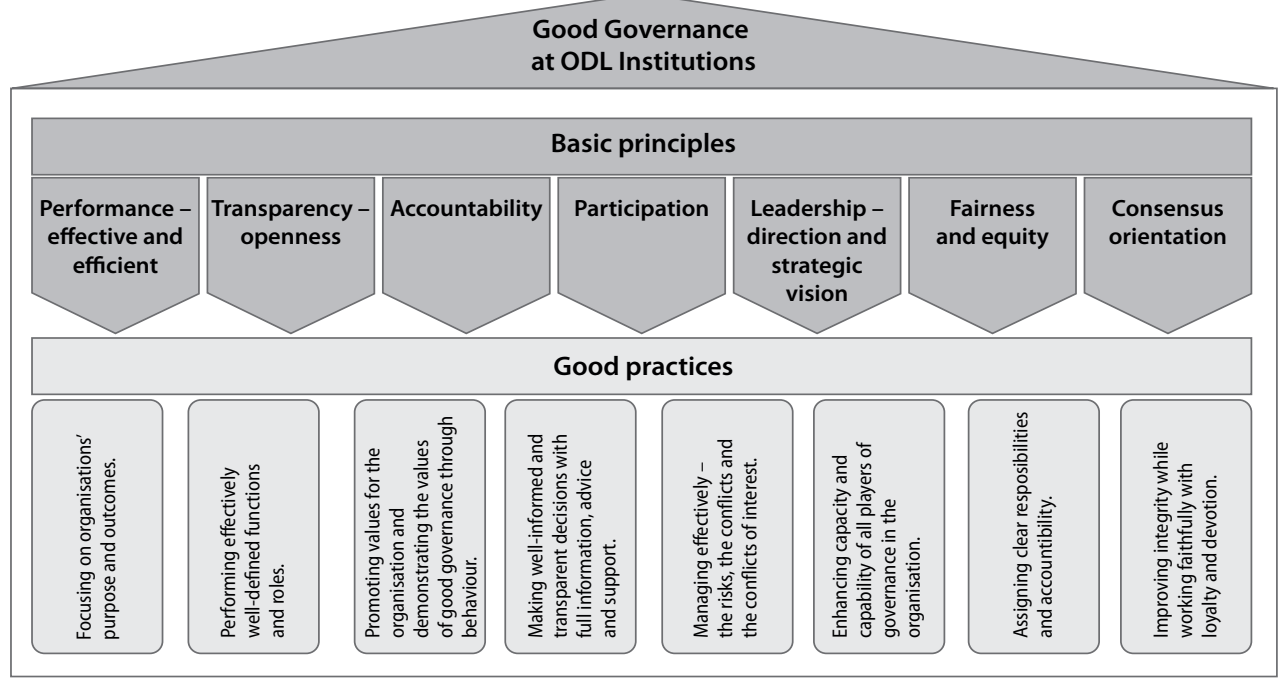

Figure 1. Good governance framework. Source: Khanna, 'A Conceptual Framework'

18 Bekele, The Challenges and Prospects.

19 ESCAP Annual Report 2014, United Nations, Economic and Social Commission for Asia and the Pacific.

20 P Khanna, 'A Conceptual Framework for Achieving Good Governance at Open and Distance Learning Institutions', Open Learning: The Journal of Open, Distance, and e-Learning 32, no 1 (2017), 21-35.

21 ESCAP Annual Report 2014.

22 Khanna, 'A Conceptual Framework. 


\section{Research methodology}

\subsection{Study design}

The study deals with the assessment of the implementation of good governance practices while rendering services to the citizens. This type of inquiry favours the use of an explanatory type of research. This study used two kinds of data collection methods, quantitative and qualitative, with closed and open-ended questionnaires, interviews, and focus group discussions (FGDs) to capture in-depth and wider data for the analysis. Interviews provide data very different from observations. Thus, an unstructured interview was conducted with service providers. Focused group discussions and document reviews were also used to support the results obtained from the structured questionnaires. The questionnaires were distributed for the respondents to be filled in with the help of data collectors.

Although the results of the research might highly be dependent on the primary data that were gathered through the questionnaires and discussions, document reviews were also important to clearly understand the concepts and results of the implementation. Instead of concentrating only on the responses of the structured questionnaires, the researchers triangulate the data gathered from different sources. Thus, the triangulation constitutes a rigorous scientific approach to compensate for the weaknesses in the collection and analysis of the data, and make the research findings reliable.

Data quality was assured using appropriate data collection process techniques such as giving orientation to data collectors about the contents of the questionnaires and frequent supervisions; data collectors assisted the respondents in case of difficulties; reported problems were countered at the time of data collection immediately by the researchers; appropriate measures were taken. Questionnaires were checked for missing values and inconsistency. Those found to have many missing values and inconsistencies were excluded from the study and considered as non-respondents. Finally, data coding and entry were made by the principal investigators with the help of data entry professionals.

\subsection{Population and sample size}

The target population of this study was all customers receiving services from city administration offices. For the data collection, through purposive sampling, the Yeka sub-city was selected. This type of purposive selection was because of consistency, time, and cost for the study. From this sub-city, three district administration offices were selected. Finally, respondents were randomly chosen. To come up with 
conservative sample size, as cited by Sisay, ${ }^{23}$ Kothari ${ }^{24}$ advises researchers to take the value of $\mathrm{p}=0.5$ where $\mathrm{n}$ would be the maximum and the sample would yield at least the desired precision. This would be the most conservative sample size assuming a 95 per cent confidence level and $\mathrm{P}$ to be 50 per cent. In this regard, Cochran provided a simplified formula to calculate a sample size when information about the population is not available. ${ }^{25}$ Here, it is difficult to get information about the total population of the study area who is being served permanently from the institutions.

$n=p q z 2 / e 2$

where $\mathrm{n}=$ desired sample size;

$\mathrm{p}=$ population proportion $(0.5)$;

$\mathrm{Z}$ = confidence level (1.96);

$\mathrm{q}=$ the value derived (0.5);

$\mathrm{e}=$ acceptable error (0.05).

The sample size in this study is 384 respondents and has been calculated drawing on the above formula. To compensate for non-responses, additional (40 per cent) respondents were included in the study. Accordingly, 538 copies of the questionnaires were distributed to the respondents. The respondents focused on those customers of the institutions that have been served on the particular days of data collection. After collecting and cleaning the data, 520 questionnaires were used for the analysis.

\subsection{Data collection instruments}

Primary and secondary data were gathered using data collection instruments. Primary data were collected using data collection instruments that include structured and unstructured questionnaires, interviews, and questions for focused group discussions. The secondary data were collected from different related documents from the administration offices. In the questionnaires, there were both close-ended and open-ended non-numerical questions. The closed-ended quantitative method was organised using the Likert five scale format (considered on a 1-5 points scale, where 1 represents the lowest level of satisfaction or high disagreement, whereas 5 represents the highest level of satisfaction or high agreement). The points of scale indicate the degree of satisfaction or agreement level of the respondents. It is also used to increase the response rate and response quality along with reducing respondents' frustration

23 A Sisay, A Dvivedi and B Beshah: 'Determinants of Job Satisfaction in Ethiopia: Evidence from the Leather Industry', African Journal of Economic and Management Studies 9, no 4 (2018).

24 CR Kothari, Research Methodology: Methods and Techniques (New Delhi: New Age International, 2004).

25 W Cochran, Sampling Techniques, 3rd Ed. (New York: Wiley, 1977). 
level. The secondary data were gathered from the documents of the institutions and research findings of various scholars on the topic under investigation.

\subsection{Data processing and analysis method}

After the completion of data collection, coding and organising the data was used for data analysis. Data editing and entering happened while checking the consistency and validity of data collected with different tools. Both quantitative and qualitative data were used for the analysis. The IBM SPSS statistical package version 21 was used to make the quantitative analysis of data that was collected through questionnaires. The SPSS statistical frequency was used for descriptive analysis. Qualitative analysis was employed for the data collected through interviews and focused group discussions (FGDs). The qualitative analysis was done to supplement the quantitative analysis. The results of the study analysis were expressed in number, percentage, and qualitative expression.

\section{Results and discussions}

\subsection{Background information}

In this chapter, details are given on the items of the assessment of implementation of good governance in service provisions to the citizens. Different items are used for the assessment. Thus, the study focused on the customers of the institutions. There has been extensive deliberation about the best way to quantify items of the assessment. As a result of the difficulty in defining measurement methodologies of assessment, different approaches have been emerged. Assessment of the implementation process includes perceptions of how well the results have been achieved. The customers' perception in the assessment process is used as an instrument for identifying the gap between the desired results and achieved results in the implementation process of good governance in the institutions. Thus, the study focused on structured questionnaires, focused group discussions and interviews.

The background information of the service providers is important regarding professional responses from the respondents. The information includes position, total work experience, educational background of service providers. Most of the service providers (83.3 per cent) are experts and team leaders who are familiar with services provided for the customers of the institutions. In terms of educational background, most of them (97.6 per cent) were first degree holders. The data also shows that most of the respondents (31 per cent) have service experience of above five years in their current institutions.

As indicated in the methodology section, 600 questionnaires were distributed to the respondents, out of which 520 were correctly filled and returned. In addition to the structured questionnaire, three focused group discussions and interviews were 
conducted with the customers of the institutions. The data analysis, interpretation and results are described as follows.

\subsection{Good governance is effective and efficient}

Good governance requires all concerned institutions to be performed effectively and efficiently as per the functions, operations, roles, and responsibilities assigned. This implies that, the implementation of good governance at the institutions yield significant outcomes, impacted positively on the lives of stakeholders, while considering the efficient use of the available resources. As can be observed from Table 1, the respondents are indicated in the items related to efficiency and effectiveness. The responses of the individual items in Table 1, however, reveal differences among respondents. Accordingly, 25.7 per cent of the total respondents are below the moderate level, while 74.3 per cent of them are on the moderate and above levels. The findings show that the institutions' efficiency and effectiveness are good.

Table 1. Effective and efficient governance

\begin{tabular}{|c|c|c|c|c|c|c|c|c|}
\hline \multirow[t]{2}{*}{ No. } & \multirow{2}{*}{\multicolumn{2}{|c|}{ Items }} & \multicolumn{5}{|c|}{ Responses } & \multirow{3}{*}{$\begin{array}{r}\text { Total } \\
520 \\
\end{array}$} \\
\hline & & & \multirow{2}{*}{$\begin{array}{r}\begin{array}{r}\text { Str. } \\
\text { disagree }\end{array} \\
44\end{array}$} & \multirow{2}{*}{\begin{tabular}{r|} 
Disagree \\
214
\end{tabular}} & \multirow{2}{*}{$\begin{array}{r}\text { Moderate } \\
162\end{array}$} & \multirow{2}{*}{\begin{tabular}{r|} 
Agree \\
80
\end{tabular}} & \multirow{2}{*}{\begin{tabular}{r|}
$\begin{array}{r}\text { Str. } \\
\text { agree }\end{array}$ \\
20
\end{tabular}} & \\
\hline Q1 & Do institutions & Frequency & & & & & & \\
\hline & work effectively & Percentage & 8.5 & 41.2 & 31.2 & 15.4 & 3.8 & 100 \\
\hline & $\begin{array}{l}\text { as per the } \\
\text { customers' } \\
\text { request? }\end{array}$ & $\begin{array}{l}\text { Cumulative } \\
\text { percentage }\end{array}$ & 8.5 & 49.7 & 65.1 & 96.2 & 100 & \\
\hline \multirow[t]{3}{*}{ Q2 } & \multirow{3}{*}{$\begin{array}{l}\text { Do institutions } \\
\text { use public } \\
\text { resources } \\
\text { effectively? }\end{array}$} & Frequency & 171 & 124 & 147 & 33 & 45 & 520 \\
\hline & & Percentage & 32.9 & 23.8 & 28.3 & 6.3 & 8.7 & 100 \\
\hline & & \begin{tabular}{|l|} 
Cumulative \\
percentage
\end{tabular} & 32.9 & 56.7 & 63 & 91.3 & 100 & \\
\hline \multirow[t]{3}{*}{ Q3 } & \multirow{3}{*}{$\begin{array}{l}\text { Do institutions } \\
\text { provide quality } \\
\text { services to their } \\
\text { customers? }\end{array}$} & Frequency & 156 & 191 & 89 & 34 & 50 & 520 \\
\hline & & Percentage & 30 & 36.7 & 17.1 & 6.5 & 9.6 & 100 \\
\hline & & $\begin{array}{l}\text { Cumulative } \\
\text { percentage }\end{array}$ & 30 & 66.7 & 83.8 & 90.4 & 100 & \\
\hline \multirow[t]{3}{*}{ Q4 } & \multirow{3}{*}{$\begin{array}{l}\text { Do institutions } \\
\text { have follow-up } \\
\text { and supporting } \\
\text { systems? }\end{array}$} & Frequency & 166 & 145 & 96 & 77 & 36 & 520 \\
\hline & & Percentage & 31.9 & 27.9 & 18.5 & 14.8 & 6.9 & 100 \\
\hline & & \begin{tabular}{|l|} 
Cumulative \\
percentage
\end{tabular} & 31.9 & 58.9 & 77.4 & 92.2 & 100 & \\
\hline \multicolumn{3}{|c|}{ Average percentage } & 25.83 & 32.40 & 23.78 & 10.75 & 7 & 100 \\
\hline \multicolumn{3}{|c|}{ Overall cumulative percentage } & 25.83 & 58.00 & 72.33 & 93 & 100 & \\
\hline
\end{tabular}

Source: Survey by the authors, 2019. 
According to Hailu, ${ }^{26} \mathrm{Meretu}^{27}$ and Alemu, ${ }^{28}$ the inefficiencies and ineffective processes of organisational structure and management practices affected the governance system of the public sectors in Ethiopia. Dibaba said that despite the endowed resources of the country that can bring about economic miracles and development in the country, due to poor governance, the economic and social indicators of the country are among the lowest. ${ }^{29}$ Thus, the findings of this study support Dibaba's analysis. The institutions' performance in effectiveness and efficiency is not better than acceptable. The institutions do not work effectively as per the customers' demand; use no public resources effectively; do not provide quality services to their customers and have a poor follow-up and supporting system. Though the performance shows favourable results, focused group discussions and interviews identified problems that include lack of infrastructures; low awareness in the system of resource utilisation; low commitment of service provisions; lack of service quality; and lack of basic necessary knowledge, skills, and attitude of service providers.

\subsection{Good governance is transparent and open}

Transparency indicates that public information should be accessible in an easily understandable system that should be freely available and directly accessible to stakeholders or citizens who will be affected by the policies, strategies and practices of the government. Openness as a leadership quality has many important things in it. The importance of transparency and openness in the organisation is the acceptance of the new ideas by the leadership. As can be observed from Table 2, responses from the individual items in the table reveal different reactions among respondents. Accordingly, 68.7 per cent of the total respondents indicated a value below the moderate level, while 31.8 per cent of them agree to a moderate level and above. As prior findings, this also shows that the institutions have the governance system that is not transparent and open while providing services to the clients.

The institution should also evaluate the progress of the implementation made towards the targets and disclose information along with other relevant information as required by the citizens. The service providers in the concerned institution should be as open as possible about all the decisions and actions that they take. According to Hailu ${ }^{30}$ and Legas, ${ }^{31}$ the institutions have not been found effective in transparency and openness. Ostensibly, this study found the same results. The findings indicate

26 S Hailu, 'Challenges and Prospects of Good Governance in Ethiopia: The Case of Kemisie Town, Ethiopia', International Journal of Political Science and Development 6, no 4 (2018).

27 TM Abuhay, 'Assessing the Prevalence of Good Governance in Public Sectors in Gedeo Zone: Case of Yirga Cheffe Town Administration', Journal for Studies in Management and Planning 1, no 8 (2015), 37-49.

28 Alemu and Lemma, 'The Contribution.'

29 Dibaba, 'Opportunities and Challenges'.

30 Hailu, 'Challenges and Prospects'.

31 Legas, Parliamentary Oversight. 
that institutions have policies and strategies, but failed to distribute all information openly and timely to the public. The participants of focus group discussion and key informants reflect the same outcomes as in the quantitative findings in Table 2.

Table 2. Transparent and open governance

\begin{tabular}{|c|c|c|c|c|c|c|c|c|}
\hline \multirow[t]{2}{*}{ No. } & \multirow{2}{*}{\multicolumn{2}{|c|}{ Items }} & \multicolumn{5}{|c|}{ Responses } & \multirow{3}{*}{$\begin{array}{c}\text { Total } \\
520\end{array}$} \\
\hline & & & \multirow{2}{*}{$\begin{array}{r}\text { Str. } \\
\text { disagree } \\
198\end{array}$} & \multirow{2}{*}{\begin{tabular}{r|} 
Disagree \\
160 \\
\end{tabular}} & \multirow{2}{*}{$\begin{array}{r}\text { Moderate } \\
94\end{array}$} & \multirow{2}{*}{$\begin{array}{r}\text { Agree } \\
36\end{array}$} & \multirow{2}{*}{$\begin{array}{r}\begin{array}{r}\text { Str. } \\
\text { agree }\end{array} \\
32 \\
\end{array}$} & \\
\hline Q1 & Do institutions & Frequency & & & & & & \\
\hline & have policies & Percentage & 38.1 & 30.8 & 18.1 & 6.9 & 6.2 & 100 \\
\hline & $\begin{array}{l}\text { and strategies of } \\
\text { service provisions? }\end{array}$ & $\begin{array}{l}\text { Cumulative } \\
\text { percentage }\end{array}$ & 38.1 & 68.9 & 87 & 93.9 & 100 & \\
\hline \multirow[t]{3}{*}{ Q2 } & \multirow{3}{*}{$\begin{array}{l}\text { Do institutions } \\
\text { transparently } \\
\text { distribute all } \\
\text { information? }\end{array}$} & Frequency & 146 & 201 & 86 & 63 & 24 & 520 \\
\hline & & Percentage & 28.1 & 38.7 & 16.5 & 12.1 & 4.6 & 100 \\
\hline & & $\begin{array}{l}\text { Cumulative } \\
\text { percentage }\end{array}$ & 28.1 & 66.8 & 83.3 & 95.4 & 100 & \\
\hline \multirow[t]{3}{*}{ Q3 } & \multirow{3}{*}{$\begin{array}{l}\text { Do institutions } \\
\text { openly distribute } \\
\text { timely information } \\
\text { to the public? }\end{array}$} & Frequency & 189 & 192 & 88 & 35 & 16 & 520 \\
\hline & & Percentage & 36.3 & 36.9 & 16.9 & 6.7 & 3.1 & 100 \\
\hline & & $\begin{array}{l}\text { Cumulative } \\
\text { percentage }\end{array}$ & 36.3 & 73.2 & 90.1 & 96.8 & 100 & \\
\hline \multirow[t]{3}{*}{ Q4 } & \multirow{3}{*}{$\begin{array}{l}\text { Do institutions } \\
\text { openly accept } \\
\text { questions and } \\
\text { provide services } \\
\text { to the customers } \\
\text { timely? }\end{array}$} & Frequency & 186 & 157 & 87 & 68 & 22 & 520 \\
\hline & & Percentage & 35.8 & 30.2 & 16.7 & 13.1 & 4.2 & 100 \\
\hline & & $\begin{array}{l}\text { Cumulative } \\
\text { percentage }\end{array}$ & 35.8 & 66 & 82.7 & 95.8 & 100 & \\
\hline \multicolumn{3}{|c|}{ Average percentage } & 34.58 & 34.15 & 17.05 & 9.70 & 4.52 & 100 \\
\hline \multicolumn{3}{|c|}{ Overall cumulative percentage } & 34.58 & 68.73 & 85.78 & 95.48 & 100 & \\
\hline
\end{tabular}

Source: Survey by the authors, 2019.

\subsection{Good governance is accountable}

Accountability is a fundamental requirement of good governance. An institution should report, explain, and be answerable for the consequences of decisions it has made on behalf of the community it serves. As can be observed from Table 3, the respondents responded to the items related to accountability. The responses to the individual items in the table were different. Accordingly, 68.45 per cent of the total respondents indicated a value below the moderate level, while 31.55 per cent indicated a value at moderate level and above. The findings indicate that institutions have not been practicing accountability. 
Government institutions are accountable to the applicable rules of law. According to Legas, ${ }^{32}$ accountability is an important quality for effective leadership. Though the implementation of accountability is representative of a successful public sector institutional reform program, its implementation process is complex. ${ }^{33}$ According to Bekele, ${ }^{34}$ the autocratic or patron-client relations in the political process, the involvement of public servants in private business, poor service conditions, a decline of professionalism, and ethnicity contributed to the deterioration of the accountability in Ethiopia. Thus" this study reveals similar results. The findings of the study indicate unfavourable results in terms of accountability. Therefore, informants and focused group discussions identified weak accountability in decision-making processes; high level of corruption and discrimination.

Table 3. Governance that is accountable

\begin{tabular}{|c|c|c|c|c|c|c|c|c|}
\hline \multirow[t]{2}{*}{ No. } & \multirow{2}{*}{\multicolumn{2}{|c|}{ Items }} & \multicolumn{5}{|c|}{ Responses } & \multirow{3}{*}{$\begin{array}{l}\text { Total } \\
520 \\
\end{array}$} \\
\hline & & & \multirow{2}{*}{\begin{tabular}{r|}
$\begin{array}{r}\text { Str. } \\
\text { disagree }\end{array}$ \\
195 \\
\end{tabular}} & \multirow{2}{*}{\begin{tabular}{r|} 
Disagree \\
172 \\
\end{tabular}} & \multirow{2}{*}{$\begin{array}{r}\text { Moderate } \\
104 \\
\end{array}$} & \multirow{2}{*}{\begin{tabular}{r|} 
Agree \\
21 \\
\end{tabular}} & \multirow{2}{*}{\begin{tabular}{r|}
$\begin{array}{r}\text { Str. } \\
\text { agree }\end{array}$ \\
28 \\
\end{tabular}} & \\
\hline Q1 & Do institutions & Frequency & & & & & & \\
\hline & pass decisions & Percentage & 37.5 & 33.1 & 20 & 4 & 5.4 & 100 \\
\hline & $\begin{array}{l}\text { timely and are } \\
\text { accessible to } \\
\text { customers? }\end{array}$ & $\begin{array}{l}\text { Cumulative } \\
\text { percentage }\end{array}$ & 37.5 & 70.5 & 90.5 & 94.5 & 100 & \\
\hline \multirow[t]{3}{*}{ Q2 } & \multirow{3}{*}{$\begin{array}{l}\text { Do institutions } \\
\text { have practical } \\
\text { accountability } \\
\text { systems? }\end{array}$} & Frequency & 196 & 141 & 89 & 68 & 28 & 520 \\
\hline & & Percentage & 37.7 & 27.1 & 17.1 & 13 & 5 & 100 \\
\hline & & $\begin{array}{l}\text { Cumulative } \\
\text { percentage }\end{array}$ & 37.7 & 64.8 & 81.9 & 94.9 & 100 & \\
\hline \multirow[t]{3}{*}{ Q3 } & \multirow{3}{*}{$\begin{array}{l}\text { Do institutions } \\
\text { understand } \\
\text { that they are } \\
\text { accountable } \\
\text { to their } \\
\text { customers? }\end{array}$} & Frequency & 199 & 181 & 78 & 35 & 28 & 520 \\
\hline & & Percentage & 38.3 & 34.8 & 15 & 6.7 & 5.2 & 100 \\
\hline & & $\begin{array}{l}\text { Cumulative } \\
\text { percentage }\end{array}$ & 38.3 & 73.1 & 88.1 & 94.8 & 100 & \\
\hline \multirow[t]{3}{*}{ Q4 } & \multirow{3}{*}{$\begin{array}{l}\text { Do institutions } \\
\text { understand } \\
\text { their rights and } \\
\text { duties? }\end{array}$} & Frequency & 205 & 135 & 82 & 83 & 15 & 520 \\
\hline & & Percentage & 39.4 & 26 & 15.8 & 16 & 2.9 & 100 \\
\hline & & $\begin{array}{l}\text { Cumulative } \\
\text { percentage }\end{array}$ & 39.4 & 65.4 & 81.2 & 97.2 & 100 & \\
\hline \multicolumn{3}{|c|}{ Average percentage } & 38.23 & 30.25 & 16.98 & 9.93 & 5 & 100 \\
\hline \multicolumn{3}{|c|}{ Overall cumulative percentage } & 38.23 & 68.45 & 85.43 & 95 & 100 & \\
\hline
\end{tabular}

Source: Survey by the authors, 2019.

32 Legas, Parliamentary Oversight.

33 Worku, Assessment.

34. Bekele, The Challenges and Prospects. 


\subsection{Good governance is participatory}

Participation refers to a process whereby leaders invite citizens or stakeholders on their issues. Citizens have to have access to information, ask for their opinion, give the opportunity to make recommendations and be part of the decision-making process. This will improve the overall development of the country. In other words, everyone concerned would have an opportunity to participate freely in the governance of the institution. As a result, such goodK participation would help the administrative management in creating an environment of good governance..$^{35}$ Participation by both men and women in their concerns, either directly or through legitimate representatives, is a key cornerstone of good governance. As observed in Table 4, the respondents responded to the items related to participation. The observation of the individual items in the table, however, reveals different responses among respondents. Accordingly, 70.05 per cent of the total respondents indicated a value below the moderate level, while 29.95 per cent indicated a value at moderate level and above. The data shows that the institutions have not been implementing the participatory approach while making public decisions.

Table 4. Participatory governance

\begin{tabular}{|c|c|c|c|c|c|c|c|c|}
\hline \multirow[t]{2}{*}{ No. } & \multirow{2}{*}{\multicolumn{2}{|c|}{ Items }} & \multicolumn{5}{|c|}{ Responses } & \multirow{3}{*}{$\begin{array}{r}\text { Total } \\
520\end{array}$} \\
\hline & & & \multirow{2}{*}{$\begin{array}{r}\begin{array}{r}\text { Str. } \\
\text { disagree }\end{array} \\
224\end{array}$} & \multirow{2}{*}{\begin{tabular}{r|} 
Disagree \\
169
\end{tabular}} & \multirow{2}{*}{\begin{tabular}{r|} 
Moderate \\
88
\end{tabular}} & \multirow{2}{*}{$\begin{array}{r}\text { Agree } \\
22\end{array}$} & \multirow{2}{*}{\begin{tabular}{r|}
$\begin{array}{r}\text { Str. } \\
\text { agree }\end{array}$ \\
17
\end{tabular}} & \\
\hline Q1 & Do institutions & Frequency & & & & & & \\
\hline & let customers & Percentage & 43.1 & 32.5 & 16.9 & 4.2 & 3.3 & 100 \\
\hline & $\begin{array}{l}\text { making core } \\
\text { decisions? }\end{array}$ & $\begin{array}{l}\text { Cumulative } \\
\text { percentage }\end{array}$ & 43.1 & 75.6 & 92.5 & 96.7 & 100 & \\
\hline \multirow[t]{3}{*}{ Q2 } & \multirow{3}{*}{$\begin{array}{l}\text { Do institutions } \\
\text { listen to the voice } \\
\text { of customers? }\end{array}$} & Frequency & 231 & 125 & 95 & 56 & 13 & 520 \\
\hline & & Percentage & 44.4 & 24 & 18.3 & 10.8 & 2.5 & 100 \\
\hline & & \begin{tabular}{|l|}
$\begin{array}{l}\text { Cumulative } \\
\text { percentage }\end{array}$ \\
\end{tabular} & 44.4 & 68.4 & 86.7 & 97.5 & 100 & \\
\hline \multirow[t]{3}{*}{ Q3 } & \multirow{3}{*}{$\begin{array}{l}\text { Do institutions } \\
\text { provide customers } \\
\text { their rights? }\end{array}$} & Frequency & 209 & 167 & 80 & 43 & 21 & 520 \\
\hline & & Percentage & 40.2 & 32.1 & 15.4 & 8.3 & 4 & 100 \\
\hline & & \begin{tabular}{|l|}
$\begin{array}{l}\text { Cumulative } \\
\text { percentage }\end{array}$ \\
\end{tabular} & 40.2 & 72.3 & 87.7 & 96 & 100 & \\
\hline \multirow[t]{3}{*}{ Q4 } & \multirow{3}{*}{$\begin{array}{l}\text { Do institutions } \\
\text { provide customers } \\
\text { their rights to } \\
\text { express their ideas } \\
\text { freely? }\end{array}$} & Frequency & 197 & 117 & 106 & 77 & 23 & 520 \\
\hline & & \begin{tabular}{|l|} 
Percentage \\
\end{tabular} & 37.9 & 26 & 15.8 & 16 & 2.9 & 100 \\
\hline & & $\begin{array}{l}\text { Cumulative } \\
\text { percentage }\end{array}$ & 37.9 & 63.9 & 79.7 & 95.7 & 100 & \\
\hline \multicolumn{3}{|c|}{ Average percentage } & 41.4 & 26.65 & 16.6 & 9.83 & 3.18 & 100 \\
\hline \multicolumn{3}{|c|}{ Overall cumulative percentage } & 41.4 & 70.05 & 86.65 & 96.48 & 100 & \\
\hline
\end{tabular}

Source: Survey by the authors, 2019.

35 Khanna, 'A Conceptual Framework'. 
Hailu ${ }^{36}$ and Legas ${ }^{37}$ found that societal participation is in progress but the participants of women and youth are constrained by harmful traditional practices. Thus, the findings of the study indicate unfavourable results in terms of participation. The institutions do not involve all customers while making core decisions; do not listen to the voice or ideas of the customers and the customers do not have the practical right to express their ideas freely. Therefore, weak accountability in decision-making processes and unfair opportunities in participation were the major problems identified.

\subsection{Leadership direction and strategic vision}

Leadership is about setting the directions, developing the culture of the organisation, determining its principles and values, and motivating the people in the organisation to commit themselves to those principles and values. The respondents responded to the items related to leadership direction and strategic vision. The responses on service providers, which encompasses commitment, leadership skills, institutional vision, and equal treatment of customers, were different. Accordingly, 66.58 per cent of the total respondents indicated a value below the moderate level, while 33.42 per cent indicated a value at moderate level and above. The result shows that the institutions' practice in leadership direction and strategic vision is not being practiced as well.

Leaders are expected to plan and direct an appropriate strategy. They are also expected to make effective arrangements to ensure that a good management system, including a decision-making system, is in place for the satisfactory operation and management of the institution. ${ }^{38}$ According to Amedie, ${ }^{39}$ the performance of Addis Ababa city administration indicated that there is an ill commitment of leaders at all levels of the administration. The poor capacity and absence of skilled staff resulted in poor service delivery processes. The magnitude of the challenges is more characteristic of the woreda administration office level where more services are required by the citizens in the city. Lack of effective leadership is the main cause of Africa's lagging from the rest of the world. ${ }^{40}$ The findings of the study indicate favourable results in terms of leadership style with some limitations. The institutions have work commitment; have leadership skills; have an institutional vision, and treat all customers equally. The problems identified were lack of leaders' administrative skill and knowledge; lack of implementing policies directed from the regional government; weak interaction and relationship between people and leaders; low awareness in understanding the vision of the institutions; and lack of strategic planning for the implementation processes.

36 Hailu, 'Challenges and Prospects'.

37 Legas, Parliamentary Oversight.

38 MO Onolememen, The Impact of Leadership on the Governance of Infrastructure Development in Nigeria, PhD Dissertation, Walden University, Nigeria, 2015.

39 Amedie, The Significance and Practice.

40 Bekele, The Challenges and Prospects. 
Table 5. Direction and strategic vision of leadership

\begin{tabular}{|c|c|c|c|c|c|c|c|c|}
\hline \multirow[t]{2}{*}{ No. } & \multirow{2}{*}{\multicolumn{2}{|c|}{ Items }} & \multicolumn{5}{|c|}{ Responses } & \multirow{3}{*}{$\begin{array}{l}\text { Total } \\
520\end{array}$} \\
\hline & & & \multirow{2}{*}{$\begin{array}{r}\text { Str. } \\
\text { disagree } \\
185\end{array}$} & \multirow{2}{*}{$\begin{array}{r}\text { Disagree } \\
205\end{array}$} & \multirow{2}{*}{$\begin{array}{r}\text { Moderate } \\
100\end{array}$} & \multirow{2}{*}{\begin{tabular}{r|} 
Agree \\
20
\end{tabular}} & \multirow{2}{*}{$\begin{array}{r}\begin{array}{r}\text { Str. } \\
\text { agree }\end{array} \\
10\end{array}$} & \\
\hline \multirow[t]{3}{*}{ Q1 } & \multirow{3}{*}{$\begin{array}{l}\text { Do leaders set } \\
\text { direction \& } \\
\text { strategic vision? }\end{array}$} & Frequency & & & & & & \\
\hline & & Percentage & 35.5 & 39.4 & 19.2 & 3.8 & 2 & 100 \\
\hline & & $\begin{array}{l}\text { Cumulative } \\
\text { percentage }\end{array}$ & 35.5 & 74.9 & 94.1 & 98 & 100 & \\
\hline \multirow[t]{3}{*}{ Q2 } & \multirow{3}{*}{$\begin{array}{l}\text { Do leaders treat } \\
\text { customers with } \\
\text { care? }\end{array}$} & Frequency & 170 & 165 & 98 & 40 & 47 & 520 \\
\hline & & Percentage & 32.5 & 31.7 & 18.9 & 7.7 & 9 & 100 \\
\hline & & $\begin{array}{l}\text { Cumulative } \\
\text { percentage }\end{array}$ & 32.5 & 64.2 & 83.1 & 90.8 & 100 & \\
\hline \multirow[t]{3}{*}{ Q3 } & \multirow{3}{*}{$\begin{array}{l}\text { Do leaders have } \\
\text { skills to direct } \\
\text { organisations? }\end{array}$} & Frequency & 150 & 201 & 89 & 50 & 30 & 520 \\
\hline & & Percentage & 28.9 & 38.7 & 17.1 & 9.6 & 5.7 & 100 \\
\hline & & $\begin{array}{l}\text { Cumulative } \\
\text { percentage }\end{array}$ & 28.9 & 67.6 & 84.7 & 94.3 & 100 & \\
\hline \multirow[t]{3}{*}{ Q4 } & \multirow{3}{*}{$\begin{array}{l}\text { Do leaders } \\
\text { motivate } \\
\text { employees at the } \\
\text { organisations? }\end{array}$} & Frequency & 165 & 145 & 96 & 100 & 14 & 520 \\
\hline & & Percentage & 31.7 & 27.9 & 18.5 & 19.2 & 2.6 & 100 \\
\hline & & $\begin{array}{l}\text { Cumulative } \\
\text { percentage }\end{array}$ & 31.7 & 59.6 & 78.1 & 97.3 & 100 & \\
\hline \multicolumn{3}{|c|}{ Average percentage } & 32.15 & 34.43 & 18.05 & 10.08 & 4.83 & 100 \\
\hline \multicolumn{3}{|c|}{ Overall cumulative percentage } & 32.15 & 66.58 & 85 & 95.10 & 100 & \\
\hline
\end{tabular}

Source: Survey by the authors, 2019.

\subsection{Fairness and equity}

The institutional framework that prescribes the procedures and policies of the concerned organisation would be fair and enforced effectively to create an environment of good governance, whereas equity implies being fair and just to all concerned. As observed in Table 6, the respondents responded to the items related to governance fairness and equity. The observation of the individual items in the table, however, reveals different responses among respondents. Accordingly, 72.65 per cent of the total respondents indicated a value below the moderate level, while 27.35 per cent indicated a value below at moderate level and above. The findings describe that the institutions have not been practicing the fairness and equity considerations as well.

According to Worku, ${ }^{41}$ public sector institutions were poor in considering gender equality while providing services. Therefore, the performance results indicate that the institutions have not been practicing fairness and equity considerations. On the other hand, the interview and focus group discussions supported the quantitative

41 Worku, Assessment. 
data findings. Based on focused group discussions and interviews, lack of equal opportunity and fair treatment and discrimination between rich and poor were the major problems pinpointed.

Table 6. Governance with fairness and equity

\begin{tabular}{|c|c|c|c|c|c|c|c|c|}
\hline \multirow[t]{2}{*}{ No. } & \multirow{2}{*}{\multicolumn{2}{|c|}{ Items }} & \multicolumn{5}{|c|}{ Responses } & \multirow{3}{*}{$\begin{array}{r}\text { Total } \\
520 \\
\end{array}$} \\
\hline & & & \multirow{2}{*}{$\begin{array}{r}\begin{array}{r}\text { Str. } \\
\text { disagree }\end{array} \\
190 \\
\end{array}$} & \multirow{2}{*}{$\begin{array}{r}\text { Disagree } \\
200 \\
\end{array}$} & \multirow{2}{*}{$\begin{array}{r}\text { Moderate } \\
76 \\
\end{array}$} & \multirow{2}{*}{$\begin{array}{r}\text { Agree } \\
27 \\
\end{array}$} & \multirow{2}{*}{$\begin{array}{r}\text { Str. agree } \\
27 \\
\end{array}$} & \\
\hline \multirow[t]{3}{*}{ Q1 } & \multirow{3}{*}{\begin{tabular}{|l|} 
Do institutions \\
provide fair \\
decisions to \\
their customers \\
equally?
\end{tabular}} & Frequency & & & & & & \\
\hline & & Percentage & 36.5 & 38.5 & 14.6 & 5.2 & 5.2 & 100 \\
\hline & & $\begin{array}{l}\text { Cumulative } \\
\text { percentage }\end{array}$ & 36.5 & 75 & $89 . .6$ & 94.8 & 100 & \\
\hline \multirow[t]{3}{*}{ Q2 } & \multirow{3}{*}{$\begin{array}{l}\text { Do institutions } \\
\text { consider } \\
\text { gender equality } \\
\text { while providing } \\
\text { services? }\end{array}$} & Frequency & 161 & 206 & 76 & 59 & 18 & 520 \\
\hline & & Percentage & 31 & 39.6 & 14.6 & 11.3 & 3.5 & 100 \\
\hline & & $\begin{array}{l}\text { Cumulative } \\
\text { percentage }\end{array}$ & 31 & 70.6 & 85.2 & 96.5 & 100 & \\
\hline \multirow[t]{3}{*}{ Q3 } & \multirow{3}{*}{$\begin{array}{l}\text { Do institutions } \\
\text { consider } \\
\text { religion } \\
\text { equality? }\end{array}$} & Frequency & 232 & 145 & 70 & 52 & 21 & 520 \\
\hline & & Percentage & 44.6 & 27.9 & 13.5 & 10 & 4 & 100 \\
\hline & & $\begin{array}{l}\text { Cumulative } \\
\text { percentage }\end{array}$ & 44.6 & 72.5 & 86 & 96 & 100 & \\
\hline \multirow[t]{3}{*}{ Q4 } & \multirow{3}{*}{$\begin{array}{l}\text { Do institutions } \\
\text { consider } \\
\text { culture } \\
\text { equality? }\end{array}$} & Frequency & 180 & 197 & 64 & 62 & 17 & 520 \\
\hline & & Percentage & 34.6 & 37.9 & 12.3 & 11.9 & 3.3 & 100 \\
\hline & & $\begin{array}{l}\text { Cumulative } \\
\text { percentage }\end{array}$ & 34.6 & 72.5 & 84.8 & 96.7 & 100 & \\
\hline \multicolumn{3}{|c|}{ Average percentage } & 36.68 & 35.98 & 13.75 & 9.60 & 4 & 100 \\
\hline \multicolumn{3}{|c|}{ Overall cumulative percentage } & 36.68 & 72.65 & 86.40 & 96 & 100 & \\
\hline
\end{tabular}

Source: Survey by the authors, 2019.

\subsection{Good governance is responsive in service provisions}

Responsiveness is the quality of being responsive and reacting quickly with quality service provisions. The respondents responded to the three items related to the institutions' responsiveness in service provisions. The observation of the three items - the provision of an early response to the questions of the customers; provision of quality services timely with the fair cost; and having knowledge, skills, and a positive attitude to serve the customers - reveal different responses among respondents. Accordingly, 74.03 per cent of the total respondents indicated a value below the moderate level, while 25.97 per cent responded to a moderate level and above. The findings show that the institutions have not been implementing timely responsiveness. 
Table 7. Responsive governance in service provisions

\begin{tabular}{|c|c|c|c|c|c|c|c|c|}
\hline \multirow[t]{2}{*}{ No. } & \multirow{2}{*}{\multicolumn{2}{|c|}{ Items }} & \multicolumn{5}{|c|}{ Responses } & \multirow{3}{*}{$\begin{array}{r}\text { Total } \\
\\
520\end{array}$} \\
\hline & & & \multirow{2}{*}{$\begin{array}{r}\begin{array}{r}\text { Str. } \\
\text { disagree }\end{array} \\
199\end{array}$} & \multirow{2}{*}{\begin{tabular}{r|} 
Disagree \\
220 \\
\end{tabular}} & \multirow{2}{*}{$\begin{array}{r}\text { Moderate } \\
55\end{array}$} & \multirow{2}{*}{$\begin{array}{r}\text { Agree } \\
40\end{array}$} & \multirow{2}{*}{$\begin{array}{r}\text { Str. agree } \\
6\end{array}$} & \\
\hline \multirow[t]{3}{*}{ Q1 } & \multirow{3}{*}{$\begin{array}{l}\text { Do institutions } \\
\text { response early } \\
\text { to customers' } \\
\text { questions? }\end{array}$} & Frequency & & & & & & \\
\hline & & Percentage & 38.3 & 42.3 & 10.6 & 7.7 & 1.2 & 100 \\
\hline & & $\begin{array}{l}\text { Cumulative } \\
\text { percentage }\end{array}$ & 38.3 & 80.6 & 91.2 & 98.8 & 100 & \\
\hline \multirow[t]{3}{*}{ Q2 } & \multirow{3}{*}{$\begin{array}{l}\text { Do institutions } \\
\text { provide quality } \\
\text { services to } \\
\text { the customers } \\
\text { timely? }\end{array}$} & Frequency & 170 & 210 & 80 & 28 & 32 & 520 \\
\hline & & Percentage & 32.7 & 40.4 & 15.4 & 5.4 & 6.2 & 100 \\
\hline & & $\begin{array}{l}\text { Cumulative } \\
\text { percentage }\end{array}$ & 32.7 & 73.1 & 88.5 & 93.9 & 100 & \\
\hline \multirow[t]{3}{*}{ Q3 } & \multirow{3}{*}{$\begin{array}{l}\text { Do institutions } \\
\text { have knowledge } \\
\text { of the cost } \\
\text { customers' } \\
\text { incur? }\end{array}$} & Frequency & 250 & 140 & 99 & 21 & 10 & 520 \\
\hline & & Percentage & 48.1 & 26.9 & 19 & 4 & 1.9 & 100 \\
\hline & & $\begin{array}{l}\text { Cumulative } \\
\text { percentage }\end{array}$ & 48.1 & 75 & 94 & 98 & 100 & \\
\hline \multirow[t]{3}{*}{ Q4 } & \multirow{3}{*}{$\begin{array}{l}\text { Do institutions } \\
\text { have a positive } \\
\text { attitude } \\
\text { toward serving } \\
\text { customers? }\end{array}$} & Frequency & 165 & 188 & 90 & 47 & 30 & 520 \\
\hline & & Percentage & 31.2 & 36.2 & 17.3 & 9 & 5.8 & 100 \\
\hline & & $\begin{array}{l}\text { Cumulative } \\
\text { percentage }\end{array}$ & 31.2 & 67.4 & 84.7 & 93.7 & 100 & \\
\hline \multicolumn{3}{|c|}{ Average percentage } & 37.58 & 36.45 & 15.58 & 6.53 & 3.78 & 100 \\
\hline \multicolumn{3}{|c|}{ Overall cumulative percentage } & 37.58 & 74.03 & 89.6 & 96.10 & 100 & \\
\hline
\end{tabular}

Source: Survey by the authors, 2019.

According to Dayanandan, ${ }^{42}$ good governance ensures a proper and prompt response from both sides, that is, service providers to service users. These guarantees effective and efficient utilisation of available resources and reduces or helps to avoid conflict. However, public institutions' results indicated slow and very slow speed in response to customers. The authors' study results indicated the existence of poor governance in the responsiveness. The findings of this study based on the open-ended questions, focus group discussions and interviews also prove the existence of poor governance in the responsiveness.

42 Dayanandan, 'Good Governance Practice'. 
4.9 Good governance follows the rule of law

Table 8. Governance that follows the rule of law

\begin{tabular}{|c|c|c|c|c|c|c|c|c|}
\hline \multirow[t]{2}{*}{ No. } & \multirow{2}{*}{\multicolumn{2}{|c|}{ Items }} & \multicolumn{5}{|c|}{ Responses } & \multirow{3}{*}{$\begin{array}{r}\text { Total } \\
\\
520 \\
\end{array}$} \\
\hline & & & \multirow{2}{*}{\begin{tabular}{r|}
$\begin{array}{r}\text { Str. } \\
\text { disagree }\end{array}$ \\
215 \\
\end{tabular}} & \multirow{2}{*}{$\begin{array}{r}\text { Disagree } \\
130 \\
\end{array}$} & \multirow{2}{*}{$\begin{array}{r}\text { Moderate } \\
79 \\
\end{array}$} & \multirow{2}{*}{\begin{tabular}{r|} 
Agree \\
66 \\
\end{tabular}} & \multirow{2}{*}{\begin{tabular}{|r|}
$\begin{array}{r}\text { Str. } \\
\text { agree }\end{array}$ \\
30
\end{tabular}} & \\
\hline Q1 & Do institutions & Frequency & & & & & & \\
\hline & make decisions & Percentage & 41.4 & 25 & 15.2 & 12.7 & 5.8 & 100 \\
\hline & $\begin{array}{l}\text { in accordance } \\
\text { with the rule of } \\
\text { law? }\end{array}$ & $\begin{array}{l}\text { Cumulative } \\
\text { percentage }\end{array}$ & 41.4 & 66.4 & 81.6 & 94.3 & 100 & \\
\hline \multirow[t]{3}{*}{ Q2 } & \multirow{3}{*}{$\begin{array}{l}\text { Do institutions } \\
\text { provide } \\
\text { assurance to } \\
\text { customers } \\
\text { of good } \\
\text { governance } \\
\text { in complaint } \\
\text { handling? }\end{array}$} & Frequency & 160 & 195 & 120 & 30 & 15 & 520 \\
\hline & & \begin{tabular}{|l|} 
Percentage \\
\end{tabular} & 30.8 & 37.5 & 24 & 5.8 & 2.9 & 100 \\
\hline & & $\begin{array}{l}\text { Cumulative } \\
\text { percentage }\end{array}$ & 30.8 & 68.3 & 92.3 & 98.1 & 100 & \\
\hline \multirow[t]{3}{*}{ Q3 } & \multirow{3}{*}{$\begin{array}{l}\text { Do institutions } \\
\text { have the } \\
\text { competence of } \\
\text { decision-making } \\
\text { in service } \\
\text { provisions? }\end{array}$} & Frequency & 200 & 148 & 105 & 55 & 12 & 520 \\
\hline & & Percentage & 38.5 & 28.5 & 20.2 & 10.6 & 2.3 & 100 \\
\hline & & $\begin{array}{l}\text { Cumulative } \\
\text { percentage }\end{array}$ & 38.5 & 67 & 87.2 & 97.8 & 100 & \\
\hline \multirow[t]{3}{*}{ Q4 } & \multirow{3}{*}{$\begin{array}{l}\text { Do institutions } \\
\text { respect the } \\
\text { code of conduct } \\
\text { and enforced } \\
\text { impartiality? }\end{array}$} & Frequency & 176 & 197 & 96 & 31 & 20 & 520 \\
\hline & & Percentage & 33.9 & 37.9 & 18.5 & 6 & 3.9 & 100 \\
\hline & & $\begin{array}{l}\text { Cumulative } \\
\text { percentage }\end{array}$ & 33.9 & 71.8 & 90.3 & 96.3 & 100 & \\
\hline \multicolumn{3}{|c|}{ Average percentage } & 36.15 & 32.23 & 19.48 & 8.78 & 3.72 & 100 \\
\hline \multicolumn{3}{|c|}{ Overall cumulative percentage } & 36.15 & 68.38 & 87.85 & 96.63 & 100 & \\
\hline
\end{tabular}

Source: Survey by the authors, 2019.

Rule of law means that the decisions are consistent with the legislation. Good governance requires government institutions to process design and implement the service delivery approach to serve the best interests of stakeholders within a reasonable quality and timeframe. The consistency of decisions made in accordance with the rule of law and the legal competence of decision-making government bodies and individual functionaries are the important factors for the legitimacy of the decisions and therefore for the assurance of good governance. Laws, regulations, and codes of conduct should be fair and 
enforced impartially. The respondents responded to the items related to the following: the governance follows the rule of law issues that include understanding the rules and regulations of service provisions; provision of services according to rules and regulations of the institutions; and having compliant handling systems. The observation of the individual items reveals different responses among respondents. Accordingly, 68.38 per cent of the total respondents indicated a value below the moderate level, while 31.62 per cent indicated a value at moderate level and above. The results show that the institutions have not been considering the rule of law as well.

The institutional framework that prescribes the procedures and policies of the public institutions are expected to be fair and are enforced to effectively create an environment of good governance. Thereby compliance with legal requirements that involve equal opportunities, consensus, and anti-discrimination would be achieved. The consistency of decisions made in accordance with the rule of law is the legal competence of decision making government bodies. ${ }^{43}$ However, Legas ${ }^{44}$ found that public institutions are characterized by poor performance in practicing the rule of law. On the other hand, the findings of this study indicate unfavourable results in terms of the rule of law. The institutions do not provide fair decisions according to rules and regulations of the institutions. The findings from previous research and this study reveal similar results in the implementation of the elements of good governance. Therefore, at interviews and focused group discussions, lack of continuity in applying the rule and law of the institutions were pinpointed as problems.

\section{Conclusion and recommendations}

The overall practices of good governance in the study area show that the institutions have not been found perfectly effective or failed in light of the elements of good governance: effectiveness and efficiency, transparency and openness, accountability, participation, leadership direction, fairness and equity, responsiveness and rule of law. Instead, the practices were found effective in some of the elements and ineffective in some others. The quantitative performance in the implementation of all the elements of good governance is acceptable. However, the interviews and focus group discussions showed both positive results and limitations. The positive practices dominate the limitations. Although implementation practices of the principles of good governance have brought about tangible results, it is not free from some limitations: lack of infrastructures; low awareness in the system of resources utilisation; low commitment in service provisions; lack of service quality; weak accountability in decision-making processes; high level of corruption and discrimination; unfair opportunities in participation; lack of service provision on skill and knowledge of staffs; Low awareness in understanding the vision of the institutions; and lack of continuity in applying the rule of law were the challenges pinpointed.

43 Amedie, The Significance and Practice.

44 Legas, Parliamentary Oversight. 
Therefore, the institutions should highlight success parts of the implementation process that should be developed and limitations that should deserve the attention of concerned bodies of the institutions to take corrective measures. Based on the findings and conclusion made, we have come up with the following recommendations.

- To bring effective and efficient performance, the institutions should use resources with commitment and evidence-based strategies for improvement in producing favourable results that meet the needs of the citizens. The institutions should improve efficient and effective service provisions by creating greater transparency, accountability, and applying resource maximisation principles. The institutions' staff should respect the rules and regulations of the institutions without any preconditions. Citizens have to proactively participate in all aspects of the governance process. Participation needs to be informed and organised, including freedom of expression and concern for the best interests of the stakeholders. Public institutions should allocate the citizens' resources fairly and reasonably to all without discrimination based on ethnic, gender, economic level, and political view.

- To practice transparency and openness, the institutions should build on the free flow of information. The institutions should be obliged to the rights and duties of the governance. The customers should be served with decisions that are consistent with the rules and regulations of the government. The institutions developed the goal that promote harmony among the multicultural customers and mitigated the objections of the minority to reach a broad consensus of what is in the best interest of the citizens. The customers should be responsively provided with their basic needs.

- To promote the participation of stakeholders, the institutions should practice community-based organisations. The institutions should have customers' feedback systems. The institutions should listen to customers, collect information, and analyse the data to see any trends in customers' expectations. The stakeholders who directly represent the society can strongly contribute to building good governance in the institutions.

- To provide early and timely responses to citizens, the institutions should automate the organisational structure at a one-stop shopping system. Institutions have to be proactive and quick in giving solutions for complaints of the customer. According to the rule of law of the public institutions, all service providers should be under the law. Government institutions should be abided by the laws of the city administration.

- To upgrade the knowledge, skills, and attitude of employees, institutions should provide continuous capacity building training in the area of good governance to the leaders and staff. Institutions in any of their activities are expected to be active. Institutions should correct delaying and long processes while serving the society. 
The Implementation of Good Governance Practices in Service Provisions...

\section{References}

Abuhay, TM: 'Assessing the Prevalence of Good Governance in Public Sectors in Gedeo Zone: Case of Yirga Cheffe Town Administration. Journal for Studies in Management and Planning 1, no 8 (2015), 37-49.

Alemu, T and M Lemma: 'The Contribution and Challenges of Service Delivery Reform to Promote Good Governance: A Case of Addis Ababa'. Ethiopian Journal of Public Management and Development 2, no 1 (2011).

Amedie, MC: The Significance and Practice of Good Governance in Addis Ababa, Ethiopia. The Case of Bole Sub-city. MA Thesis, Addis Ababa: Indira Gandhi National Open University, 2014.

Bekele, A: The Challenges and Prospects of Good Governance in Africa: The Case of Kenya. MA Thesis, Addis Ababa: Addis Ababa University, 2013.

Cochran, W: Sampling Techniques, $3^{\text {rd }}$ Ed. New York: Wiley, 1977.

Dayanandan, R: 'Good Governance Practice for Better Performance of Community Organizations - Myths and Realities!!' Journal of Power, Politics \& Governance 1, no 1 (2013), $10-26$.

Dibaba, S: 'Opportunities and Challenges for Good Governance in Ethiopia'. The Ethiopian Herald, October 8, 2015. Available: https://allafrica.com/stories/201510091427.html (20. 03. 2020.)

ECSU, Institute of Leadership and Good Governance. Engendering Economic Governance. Addis Ababa: Addis Ababa University, 2017.

ESCAP Annual Report 2014. United Nations, Economic and Social Commission for Asia and the Pacific. Available: www.unescap.org/sites/default/files/ESCAP-Annual-Report-2014.pdf (14. 12. 2020.)

'Good Governance.' Wikipedia. Available: https://en.wikipedia.org/wiki/Good_governance (05. 03. 2020.)

Hailu, S: 'Challenges and Prospects of Good Governance in Ethiopia: The Case of Kemisie Town, Ethiopia'. International Journal of Political Science and Development 6, no 4 (2018).

Khanna, P: 'A Conceptual Framework for Achieving Good Governance at Open and Distance Learning Institutions'. Open Learning: The Journal of Open, Distance, and e-Learning 32, no 1 (2017), 21-35. DOI: 10.1080/02680513.2016.1246246

Kothari, CR: Research Methodology: Methods and Techniques. New Delhi: New Age International, 2004.

Legas, A: Parliamentary Oversight and Its Role in Ensuring Accountability. The Case of Caffee Oromia. MA Thesis, Addis Ababa: Addis Ababa University, 2015.

Onolememen, MO: The Impact of Leadership on the Governance of Infrastructure Development in Nigeria. PhD Dissertation, Walden University, Nigeria, 2015.

Sisay, A, A Dvivedi and B Beshah: 'Determinants of Job Satisfaction in Ethiopia: Evidence from the Leather Industry'. African Journal of Economic and Management Studies 9, no 4 (2018). DOI: 10.1108/AJEMS-09-2017-0222

Umar, Z: 'Constructing the 2017 Ibrahihm Index of African Governance'. Index Report. Mo Ibrahim Foundation, October 11, 2017. Available: https://mo.ibrahim.foundation/news/2017/ constructing-2017-ibrahim-index-african-governance (12. 07. 2020.)

Worku, M: Assessment of the Prevalence of Good Governance in the Public Sector: the Case of Selected Public Institutions in the Addis Ababa City of Ethiopia. MA Thesis, Addis Ababa, Ethiopia, 2013.

Yirga, K: Assessment of the Prevalence of Good Governance in the Public Sector: The Case of Public Institutions in Debre Birhan Town. MA Thesis, Mekelle University, Ethiopia, 2010. 